\title{
Oral Immunotherapy With Egg and Milk: Changes in Peripheral Serum Cytokines Are Not Predictive Factors for Severe Adverse Reactions or for the Final Report
}

\author{
García-Lirio E1, Gonzalez Diaz C², Gonzalez Hermosa A², Gamboa P¹, Aranguren R², Sanz ML ${ }^{3}$ \\ 'Servicio de Alergología, Hospital Universitario Cruces, Barakaldo, Spain \\ ${ }^{2}$ Servicio de Pediatría, Hospital Universitario de Basurto, Bilbao, Spain \\ ${ }^{3}$ Departamento de Alergología, Clínica Universidad de Navarra, Pamplona, Spain
}

J Investig Allergol Clin Immunol 2018; Vol. 28(1): 24-28

doi: 10.18176/jiaci.0212

\begin{abstract}
Introduction: Oral immunotherapy (OIT) is a new approach in patients with food allergy. Various immunological mechanisms underlie the reversal of food allergy. In this paper, we study possible changes in peripheral cytokine patterns during OIT.

Methods: Determinations of cytokines in peripheral blood were made in children who had milk or egg allergy and who received OIT. The determinations were made before and after OIT, and again following a final repeat oral challenge a month after a diet excluding the culprit food.

Results: No significant changes were registered in the cytokines studied (IL-2, IL-4, IL-6, IL-10, IL-12, IL-17, IFN 3 time points. Similarly, no differences in cytokine pattern were observed between children who had presented anaphylaxis during OIT and those who overcame or did not overcome the final oral challenge.

Discussion: Peripheral cytokines do not undergo significant changes during the OIT process. They are not predictors of serious adverse reactions or the final result of the OIT.
\end{abstract}

Key words: Egg allergy. Milk allergy. Oral immunotherapy. Cytokines.

\section{Resumen}

Introducción: Se ha introducido la inmunoterapia oral frente a alimentos como una nueva terapia en pacientes con alergia alimentaria. Diferentes mecanismos inmunológicos han sido descritos en un intento de explicar la reversibilidad de esta situación de alergia alimentaria. En este artículo, estudiamos los posibles cambios en el patrón de citoquinas en sangre periférica a lo largo del proceso de la inmunoterapia oral. Métodos: Se realizó determinación de citokinas en sangre periférica en tantos niños con alergia a leche o huevo que realizaron inmunoterapia oral. Las determinaciones se realizaron tanto de forma previa como tras la finalización de la OIT, así como tras una reprovocación final, un mes después de seguir una dieta exenta del alimento implicado.

Resultados: No se registraron cambios significativos en las citokinas estudiadas (IL-2, IL-4, IL-6, IL-10, IL-12, IL-17, IFN y y TNF) entre ninguna de las tres determinaciones temporales. Tampoco existieron diferencias en el patrón de citokinas entre los niños que habían presentado anafilaxias durante la OIT ni entre los que superaron o no superaron la provocación final.

Discusión: Las citokinas periféricas no sufren cambios significativos a lo largo del proceso de OIT. No son factores predictivos de reacciones adversas graves ni del resultado final de la OIT.

Palabras clave: Alergia a la leche. Inmunoterapia oral. Citoquinas. 


\section{Introduction}

Food allergy is emerging as a "second wave" of the allergy epidemic, replacing the "first wave", which was dominated by respiratory allergy $[1,2]$. In the first years of life, eggs and milk are the foods that most often produce this type of reaction, which can affect up to $8 \%$ of children [3].

Allergy to eggs and milk can cause anaphylaxis and even death. Treatment involves strict avoidance of the culprit food, thus decreasing the variety of foods that can be consumed and the quality of life of patients and their families. Patients are also at risk of serious reactions due to cross contamination and dietary transgressions.

Oral immunotherapy (OIT) has been used to treat food allergy for several years. By gradually introducing increasing amounts of the culprit foods into the diet [4,5], children tolerate the intake of usual amounts of these foods. This normalization of intake also reduces the risk of anaphylaxis.

Various immunological mechanisms underlie the reversal of food allergy, including a decrease in specific $\operatorname{IgE}[6]$, an increase in specific IgG4 [7], and a decrease in the antigenspecific response of basophils [8,9]. Evidence has also been reported for the modification of the cellular immune response in OIT, with a decrease in the $\mathrm{T}_{\mathrm{H}} 2$ response $[10,11]$ and in the generation of $\mathrm{T}$ cells with a nonreactive phenotype [12]. Consequently, the response observed in these children changes from their preferred $T_{H} 2$ pattern [13] to a $T_{H} 1 / T_{H} 2$ balance pattern. In the present article, we analyze possible changes in the pattern of peripheral cytokines throughout the OIT process.

\section{Patients and Methods}

\section{Participants}

The study population comprised 48 children ( 33 boys and 15 girls) with egg allergy $(n=29)$ or milk allergy $(n=19)$. Their mean (SD) age was 7.5 (2.3) years. Twenty-seven children had multiple food allergies, while the rest were allergic to egg or milk alone. Thirty-six children had bronchial asthma, all due to dust mite allergy, and 21 had atopic dermatitis. To be included in the study the children had to fulfil all 4 of the following diagnostic criteria: (1) a clinical history of immediate allergic reaction to egg or cow milk; (2) positive in vitro specific IgE to egg white, ovalbumin, and ovomucoid in egg-allergic patients or to cow milk, $\alpha$-lactalbumin (ALA), ß-lactoglobulin (BLG), or casein in milk-allergic patients; (3) positive skin test results to egg white, ovalbumin, and ovomucoid in egg-allergic patients or cow milk, ALA, BLG and casein in milk-allergic patients; and (4) a positive open oral challenge test with scrambled egg or cow milk. This fourth criterion was not required in 12 children who had developed anaphylaxis following the ingestion of egg or milk in the previous months.

The study was approved by the local ethics committee, and all the parents provided their informed consent before the children were enrolled in the study.

\section{In Vivo Tests}

Skin prick tests were performed with commercial extracts of egg white $(10 \mathrm{mg} / \mathrm{mL})$, ovalbumin $(10 \mathrm{mg} / \mathrm{mL})$, ovomucoid (10 mg/mL), cow milk (5 mg/mL), ALA (5 mg/mL), BLG $(1 \mathrm{mg} / \mathrm{mL})$, and casein $(20 \mathrm{mg} / \mathrm{mL})$ (Laboratorio BIAL) following the recommendations of the European Academy of Allergy and Clinical Immunology [14]. The skin test results were regarded as positive if the wheal diameter was $\geq 3 \mathrm{~mm}$. A positive control of histamine $10 \mathrm{mg} / \mathrm{mL}$ and a negative control of saline $0.9 \%$ were included.

The initial open food challenges were carried out 15 days before the OIT protocol was started. The challenges were carried out with incremental doses of scrambled egg or milk, starting with a quantity of $1 / 1000$ of egg or $0.1 \mathrm{~mL}$ of cow milk and ending, 8 steps later, with the ingestion of a whole egg or $200 \mathrm{~mL}$ of cow milk. All the doses were administered at 20-minute intervals in the hospital.

OIT with egg consisted of the administration of incremental doses of dehydrated egg whites (OVO DES NM, Nutrición Médica) in 9 steps or milk according to the protocol of SEICAP [4,5]. The egg could be administered in water or orange juice. The first dose was administered in the hospital, and the subsequent doses were administered at home on a daily basis for 1 week. The dose was increased every week, and this increased dose was administered in the hospital. Finally, tolerance to 1 scrambled egg or $200 \mathrm{~mL}$ of milk was verified. Subsequently, the children had to continue consuming 1 scrambled egg at least 3 days a week or $200 \mathrm{~mL}$ of cow milk in addition to any amount of other foods containing egg (eg, cakes, omelettes) or milk (eg, cakes, sweets, yoghourt).

After 1 year of being able to consume egg or milk, without presenting symptoms on intake (eg, oral allergy syndrome, urticaria, abdominal pain), parents were advised to ensure that their children followed a diet totally free of milk or egg for 1 month followed by subsequent readministration based on the same protocol as the initial OIT. This repeat oral challenge was not carried out in cases in which the patients presented symptoms after the ingestion of egg or milk despite regular consumption and in cases where the parents did not give their consent. Egg or milk was eventually readministered to 26 children.

\section{In Vitro Tests}

\section{Specific IgE}

Specific IgE to egg white, ovalbumin, ovomucoid, cow milk, ALA, BLG, and casein was measured using the ImmunoCAP FEIA system (Thermo Fisher Scientific). Values higher than $0.35 \mathrm{kU}_{\mathrm{A}} / \mathrm{L}$ were considered positive.

\section{Cytokines}

The cytokines IL-2, IL-4, IL-6, IL-10, TNF, IFN $\gamma$, and IL-17 were assessed by flow cytometry using patient serum (BD Cytometric Bead Array [CBA] Human $\mathrm{T}_{\mathrm{H}} 1 / \mathrm{T}_{\mathrm{H}} 2 / \mathrm{T}_{\mathrm{H}} 17$ Cytokine Kit, BD Sciences). The determination was carried out prior to the start of OIT, immediately after the end of OIT in all patients and immediately before performing the final repeat oral challenge test only in those patients in whom it was performed. 


\section{Statistical Analysis}

The statistical analysis was carried out using SPSS (SPSS Inc). Quantitative data were expressed as median and interquartile range and qualitative data as frequencies. Means were compared using the Wilcoxon test for paired data. The comparisons were 2-tailed in all cases, with a $\mathrm{P}$ value of $<.05$ considered to be statistically significant.

\section{Results}

OIT was administered to 29 children (20 boys, 9 girls) with egg allergy and 19 children (13 boys, 6 girls) with milk allergy. In all children, tolerance was reached to 1 complete egg and $200 \mathrm{~mL}$ of milk. The values of specific IgE prior to OIT for egg and milk were as follows: egg white, $6.6 \mathrm{kU}_{\mathrm{A}} / \mathrm{L}$ (2.212.6); ovalbumin, $5.7 \mathrm{kU}_{\mathrm{A}} / \mathrm{L}(1.2-11.7)$; ovomucoid, $4.4 \mathrm{kU}_{\mathrm{A}} / \mathrm{L}$ (2.1-11.5); cow milk, 30.8 kU $/ \mathrm{L}(10.0-59.8) ; A L A, 6.2 \mathrm{kU}_{\mathrm{A}} / \mathrm{L}$ (0.9-17.9); BLG, 3 kU $/ \mathrm{L}$ (1.3-9.9); and casein, $19.6 \mathrm{kU}_{\mathrm{A}} / \mathrm{L}$ (8.8-37.4). Nine children experienced anaphylaxis during the procedure ( 5 with egg and 4 with milk). A repeat oral challenge was performed in 26 cases with the food involved after 1 month of an exclusion diet (16 in egg and 10 in milk). In the case of egg, 8 patients tolerated the reintroduction of egg. In the case of milk, 7 children tolerated reintroduction.

In the study population as a whole, there were no significant differences in cytokine values at baseline, completion of OIT, and the repeat oral challenge (Table). Similarly, no differences were observed between the 3 time points. No significant differences in cytokine values were recorded before the repeat oral challenge in patients who tolerated or did not tolerate this oral challenge 1 month after following a diet free of food (Table). This absence of significance extends to the other 2 points when cytokine values were determined (baseline and after completion of OIT) (data not shown).
Similarly, no significant differences were observed between the children who developed anaphylaxis and those who did not during OIT in relation to the baseline cytokine values (Table).

No statistically significant values were observed when the results were analyzed according to the food involved (milk or egg, data not shown).

\section{Discussion}

As with sublingual and parenteral immunotherapy with aeroallergens, OIT tries to reverse the imbalance in the $\mathrm{T}_{\mathrm{H}} 1 / \mathrm{T}_{\mathrm{H}} 2$ response in atopic patients. This reversal of the predominance of the $\mathrm{T}_{\mathrm{H}} 2$ response is observed indirectly as a decrease in specific $\operatorname{IgE}$ values $[6,8]$, a decrease in the results of skin tests with the allergens used in immunotherapy [3,4,8], and an increase in specific IgG4 values [7]. Changes in the specific immune response to allergens should be mediated through a change in the cytokine profile, so that there is a decrease in $\mathrm{T}_{\mathrm{H}} 2$ cytokines (IL-4, IL-6, and IL-10) in favor of a predominance of $\mathrm{T}_{\mathrm{H}} 1$-dependent cytokines (IL-2, TNF, and IFN $\gamma$ ). Several studies support that this type of treatment induces the creation of specific regulatory $\mathrm{T}$ cells that release, along with other cytokines, IL-17, IL-10, TGF $\alpha$, and TGF $\beta[10,15,16]$. Together, these immunological changes lead a high percentage of patients to acquire tolerance or desensitization to the food with which OIT is administered.

In our series, we did not detect significant changes in the serum values of any of the cytokines studied. Our data are similar to those published by other authors [17] in children with cow milk OIT, although in this group, there were significant decreases in the values of platelet-derived growth factor and vascular endothelial growth factor, neither of which cytokines was assessed in our study. However, in another series of patients with OIT with egg, significant decreases were observed in several of the $\mathrm{T}_{\mathrm{H}} 1$ and $\mathrm{T}_{\mathrm{H}} 2$ cytokines in peripheral blood at

Table. Cytokine Values (pg/mL) at the 3 Study Time-Points, Anaphylaxis During Oral Immunotherapy, and Tolerance to Oral Egg Rechallenge

\begin{tabular}{|c|c|c|c|c|c|c|c|}
\hline & IL-2 & IL-4 & IL-6 & IL-10 & IL-17 & $\mathrm{TNF}$ & $\mathrm{IFN} \gamma$ \\
\hline Baseline & $\begin{array}{c}0.10 \\
(0-1.8)\end{array}$ & $\begin{array}{c}0.54 \\
(0-1.4)\end{array}$ & $\begin{array}{c}2.2 \\
(0.82-3.28)\end{array}$ & $\begin{array}{c}0.72 \\
(0.13-1.28)\end{array}$ & $\begin{array}{c}2.69 \\
(0-6.7)\end{array}$ & $\begin{array}{c}0.48 \\
(0-1.26)\end{array}$ & $\begin{array}{c}0.27 \\
(0-0.96)\end{array}$ \\
\hline Post-OIT & $\begin{array}{c}0.12 \\
(0-1.8)\end{array}$ & $\begin{array}{c}0.68 \\
(0-1.5)\end{array}$ & $\begin{array}{c}1.22 \\
(0.82-3.08)\end{array}$ & $\begin{array}{c}0.55 \\
(0-1.35)\end{array}$ & $\begin{array}{c}1.63 \\
(0-6.6)\end{array}$ & $\begin{array}{c}0.38 \\
(0-1.63)\end{array}$ & $\begin{array}{c}0.32 \\
(0-1.09)\end{array}$ \\
\hline Before rechallenge & $\begin{array}{c}0.22 \\
(0-1.5)\end{array}$ & $\begin{array}{c}0.43 \\
(0-1.1)\end{array}$ & $\begin{array}{c}1.87 \\
(0.67-2.41)\end{array}$ & $\begin{array}{c}0.66 \\
(0-0.98)\end{array}$ & $\begin{array}{c}2.92 \\
(0-5.55)\end{array}$ & $\begin{array}{c}0.6 \\
(0-1.23)\end{array}$ & $\begin{array}{c}0.34 \\
(0-1.18)\end{array}$ \\
\hline \multicolumn{8}{|c|}{ Anaphylaxis During OIT } \\
\hline Yes & $\begin{array}{c}0.89 \\
(0.04-2.29)\end{array}$ & $\begin{array}{c}0.62 \\
(0.17-1.61)\end{array}$ & $\begin{array}{c}2.27 \\
(0.71-3.67)\end{array}$ & $\begin{array}{c}0.22 \\
(1.02-1.53)\end{array}$ & $\begin{array}{c}2.7 \\
(0.02-6.4)\end{array}$ & $\begin{array}{c}0.65 \\
(0.34-1.55)\end{array}$ & $\begin{array}{c}0.28 \\
(0-1.50)\end{array}$ \\
\hline No & $\begin{array}{c}0.1 \\
(0-1.9)\end{array}$ & $\begin{array}{c}0.51 \\
(0-1.38)\end{array}$ & $\begin{array}{c}2.18 \\
(0.86-3.32)\end{array}$ & $\begin{array}{c}0.69 \\
(0.07-1.15)\end{array}$ & $\begin{array}{c}2.04 \\
(0-6.84)\end{array}$ & $\begin{array}{c}0.28 \\
(0-0.96)\end{array}$ & $\begin{array}{c}0.25 \\
(0-0.91)\end{array}$ \\
\hline \multicolumn{8}{|c|}{ Oral Egg Rechallenge Tolerance } \\
\hline Tolerance & $\begin{array}{c}0.31 \\
(0-1.54)\end{array}$ & $\begin{array}{c}0.43 \\
(0-1.42)\end{array}$ & $\begin{array}{c}1.98 \\
(0.88-2.43)\end{array}$ & $\begin{array}{c}0.66 \\
(0-1.06)\end{array}$ & $\begin{array}{c}3.79 \\
(1.67-7.11)\end{array}$ & $\begin{array}{c}0.72 \\
(0-1.36)\end{array}$ & $\begin{array}{c}0.72 \\
(0-1.36)\end{array}$ \\
\hline No Tolerance & $\begin{array}{c}0.13 \\
(0-1.86)\end{array}$ & $\begin{array}{c}0.44 \\
(0-1.02)\end{array}$ & $\begin{array}{c}0.81 \\
(0.51-1.96)\end{array}$ & $\begin{array}{c}0.66 \\
(0-0.95)\end{array}$ & $\begin{array}{c}1.5 \\
(0-5.5)\end{array}$ & $\begin{array}{c}0.12 \\
(0-1.54)\end{array}$ & $\begin{array}{c}0 \\
(0-0.72)\end{array}$ \\
\hline
\end{tabular}


the end of OIT, although these decreases were not reproduced in our series [12].

There are several explanations for our findings. The technique used may not be sufficiently sensitive, although it is the same as that used by other authors [17]. In addition, the changes motivated by desensitization to a single allergen are not sufficiently significant to produce significant changes in peripheral blood, although a decrease in antigen-specific production of IL-5 and IL-13 was observed in studies of peripheral blood mononuclear cells stimulated with antigen after OIT with peanut [10,11], milk [18], or egg [19]. This absence of modification in peripheral blood cytokines may be due to the fact that the patients were atopic, $56 \%$ were sensitized to multiple foods, $75 \%$ had bronchial asthma due to sensitization to dust mites, and $44 \%$ had atopic dermatitis. The predominance of the $\mathrm{T}_{\mathrm{H}} 2$ response was of such magnitude that desensitization to a single allergen is not sufficient to induce significant changes in the cytokine values in peripheral blood. Given that the proportion of antigen-specific $\mathrm{T}$ lymphocytes in peripheral blood is less than $0.05 \%$, a change in the clones of lymphocytes that affect the antigens involved in the allergic response to milk or egg will be of little quantitative importance in the modification in the cytokine release pattern that leads to significant changes in peripheral blood.

Similarly, no statistically significant differences were observed in cytokine values in patients who experienced anaphylaxis during OIT compared with patients who did not present it. Thus, the pattern of cytokines in peripheral blood does not seem to differ between these populations, with the result that its determination at the beginning of OIT cannot predict the need for more cautious administration in specific patients. Other analytical parameters, such as specific IgE values, wheal diameter, and basophil activation can predict which patients have a greater risk of developing anaphylaxis during OIT $[4,5,8]$.

Initially, we assumed that the modification in this cytokine pattern would be different in patients who, after successfully finishing OIT, continued with a regular intake of the food for at least 1 year and were still able to tolerate the food after a 1-month exclusion diet. These children were eventually considered able to tolerate the food. In contrast, children who did not tolerate intake were considered to be desensitized. Although the degree of food sensitization seems to be clearly different in both populations, there are no differences in their peripheral blood cytokine pattern immediately before the repeat oral challenge or in any previous one. While we can suppose that the process underlying the immune response to the food differs from the initial situation before OIT as opposed to that observed in tolerant children, this immune change is not observed in their peripheral cytokines. A study of changes in cytokine values would probably require us to focus on cell populations with an immune function after stimulation with the antigen.

Finally, determination of the cytokines studied in peripheral blood did not reveal significant differences before or after the end of the OIT processes with milk or egg. Consequently, their values cannot identify patients at risk of developing anaphylaxis during OIT or patients with sustained desensitization to the food with which the OIT has been performed.

\section{Funding}

The authors declare that no funding was received for the present study.

\section{Conflicts of Interest}

The authors declare that they have no conflicts of interest.

\section{References}

1. Tordesillas L, Berin MC, Sampson HA. Immunology of Food Allergy. Immunity. 2017;47(1):32-50.

2. Prescott S, Allen KJ. Food allergy: Riding the second wave of the allergy epidemic. Pediatr Allergy Immunol. 2011 Mar;22(2):155-60.

3. Gupta RS, Springston EE, Warrier MR, Smith B, Kumar R, Pongracic J, et al. The prevalence, severity, and distribution of childhood food allergy in the United States. Pediatrics. 2011;128(1):e9-17.

4. Martorell A, Alonso E, Echeverría L, Escudero C, GarcíaRodríguez R, Blasco C, et al. Oral Immunotherapy for Food Allergy: A Spanish Guideline. Immunotherapy Egg and Milk Spanish Guide (ITEMS Guide). Part I: Cow Milk and Egg Oral Immunotherapy: Introduction, Methodology, Rationale, Current State, Indications, Contraindications, and oral Immunotherapy build-up Phase. I Investig Allergol Clin Immunol. 2017;27:225-37.

5. Martorell A, Alonso E, Echeverría L, Escudero C, GarcíaRodríguez $R$, et al. Oral immunotherapy for food allergy: a Spanish guideline. Egg and Milk Immunotherapy Spanish Guide (ITEMS guide). Part 2: Maintenance phase of cow milk (CM) and egg oral immunotherapy (OIT), special treatment dosing schedules. Models of dosing schedules of OIT with CM and egg. J Investig Allergol Clin Immunol. 2017;45(5):508-18.

6. Burks AW, Jones SM, Wood RA, Fleisher DM, Sicherer SH, Lindblad RW, et al. Oral immunotherapy for treatment of egg allergy in children. N Engl J Med. 2012;367:233-43.

7. Wanich N, Nowak-Wegrzyn A, Sampson HA, Shreffler WG. Allergen-specific basophil suppression associated with clinical tolerance in patients with milk allergy. J Allergy Clin Immunol. 2009;123:789-94.

8. Gamboa PM, Garcia-Lirio E, Gonzalez C, Gonzalez A, MartinezAranguren RM, Sanz ML. Is the Quantification of AntigenSpecific Basophil Activation a Useful Tool for Monitoring Oral Tolerance Induction in Children With Egg Allergy? I Investig Allergol Clin Immunol. 2016;26:25-30.

9. Vila L, Moreno A, Gamboa PM, Martinez-Aranguren R, Sanz ML. Decrease in antigen-specific CD63 basophil expression is associated with the development of tolerance to egg by SOTI in children. Pediatr Allergy Immunol. 2013;24:463-8.

10. Varshney $P$, Jones SM, Scurlock AM, Perry TT, Kemper $A$, Steele $P$, et al. A randomized controlled study of peanut oral immunotherapy: Clinical desensitization and modulation of the allergic response. J Allergy Clin Immunol. 2011;127(3):65460.

11. Gorelik M, Narisety SD, Guerrerio AL, Chichester KL, Keet CA, Bieneman $A P$, et al. Suppression of the immunologic response to peanut during immunotherapy is often transient. J Allergy Clin Immunol. 2015;135:1283-92. 
12. Fuentes-Aparicio $\mathrm{V}$, Alonso-Lebrero $\mathrm{E}$, Zapatero L, Infante $\mathrm{S}$, Lorente R, Muñoz-Fernandez MA, et al. Oral immunotherapy in hen's egg-allergic children increases a hypoproliferative subset of CD4+ T cells that could constitute a marker of tolerance achievement. Pediatr Allergy Immunol. 2012;23:648-53.

13. Palomares 0 . The role of regulatory $T$ cells in IgE-mediated food allergy. J Invest Allergol Clin Immunol. 2013;23:371-82.

14. Heinzerling LM, Burbach GJ, Edenharter G, Bachert C, BindslevJensen C, Bonini S, et al. GA 2 LEN skin test study I: GA2LEN harmonization of skin prick testing: novel sensitization patterns for inhalant allergens in Europe. Allergy. 2009;64:1498-506.

15. Fuentes-Aparicio $V$, Alonso-Lebrero $E$, Zapatero L, Infante $\mathrm{S}$, Lorente R, Muñoz-Fernández MA, et al. Induction of Treg cells after oral immunotherapy in hen's egg-allergic children. Pediatr Allergy Immunol. 2014;25:103-6.

16. Syed A, García MA, Lyu SC, Bucayu R, Kohli A, et al. Peanut oral immunotherapy results in increased antigen-induced T-cell function and hypomethylation of forkhead box protein (FOXP3). J Allergy Clin Immunol. 2014;133:500-10

17. Poza-Guedes P, Barrios Y, Fuentes V, Franco A, SánchezMachín I, Alonso $E$, et al. Downregulation of angiogenesis factors, VEGF and PDGF, after rapid IgE desensitization and oral immunotherapy in children with food allergy. Biomed Res Int. 2014;2014:372567.
18. Perezábad L, Reche M, Valbuena T, López-Fandiño R, Molina E, López-Expósito I. Oral Food Desensitization in Children With IgE-Mediated Cow's Milk Allergy: Immunological Changes Underlying Desensitization. Allergy Asthma Immunol Res. 2017:9:35.

19. Perezábad L, Reche M, Valbuena T, López-Fandiño R, Molina E, López-Expósito I. Clinical efficacy and immunological changes subjacent to egg oral immunotherapy. Ann Allergy Asthma Immunol. 2015;114:504-9.

Manuscript received November 13, 2017; accepted for publication November 13, 2017.

\section{Pedro Gamboa}

Servicio de Alergia

Hospital Universitario Cruces

Barakaldo, Spain

E-mail:

PEDROMANUEL.GAMBOASETIEN@osakidetza.eus 